CESIS Electronic Working Paper Series

Paper No. 429

\title{
On the Quality and Impact of Residential Energy Performance Certificates
}

\author{
Björn Hårsman \\ Zara Daghbashyan \\ Parth Chaudhary
}

March, 2016 


\title{
On the Quality and Impact of Residential Energy Performance Certificates
}

\author{
Björn Hårsman ${ }^{1}$, Zara Daghbashyan², Parth Chaudhary ${ }^{3}$
}

\begin{abstract}
This paper addresses quality and impact issues concerning Energy Performance Certificates (EPC) by means of a dataset based upon the Swedish EPCs for single-family houses. Assuming that the quality of the certificates plays an important role for their impact, we examine to what extent various characteristics of the firms and experts issuing the certificates are influencing their assessments of energy consumption and energy conservation. Exploiting the information on biased assessments, we also investigate the relationship between the transaction price of a house and its EPC label. Doing so, we distinguish the attributes that can be observed by visiting the house and those that a buyer only can inform herself about through the EPC.

Applying regression analyses we find that firm and expert characteristics matter quite a lot implying that the EPC-quality could be improved considerably by increasing the inter-rater reliability. The results also show that the price impact of the energy label is related to information that the buyers can obtain by visiting the house rather than to information uniquely provided by the EPCs. Hence, the EPCs per se are unlikely to stimulate energy conservation through the price mechanism.
\end{abstract}

Keywords: Residential energy performance certificates, assessments of energy consumption and conservation, inter-rater reliability, capitalization of energy efficiency, hedonic regression

JEL codes: D12; R31; Q41

Acknowledgements: The authors would like to thank the Department of Industrial Economics and Management and the Center of Excellence of Science and Innovation Studies (CESIS), KTH The Royal Institute of Technology for funding this research.

\footnotetext{
${ }^{1}$ Department of Industrial Economics and Management, Royal Institute of Technology, Stockholm, Sweden (Email: bjorn.harsman@indek.kth.se)

${ }^{2}$ Department of Industrial Economics and Management, Royal Institute of Technology, Stockholm, Sweden (Email: zara.daghbashyan@indek.kth.se)

${ }^{3}$ Department of Energy Science and Engineering, Indian Institute of Technology, Mumbai, India (Email: parth001087@gmail.com)
} 


\section{Introduction}

In line with the 2002 Energy Performance of Building Directive, most European countries are currently using energy certification as a tool to communicate the energy performance of buildings to tenants and prospective as well as current property owners. ${ }^{4}$ The underlying rational for implementing the energy certification system is the presumption that the stock of buildings has a largely untapped energy conservation potential that can be realized by providing residents and property owners with better information on their use of energy and advice on ways to reduce it. Whether the expected benefits outweigh the administrative and legal work involved to design, implement and operate such an information system across European countries is, to our knowledge, an open question. By investigating issues related to the quality and impact of energy performance certificates, EPCs, for single-family homes, this paper sheds some more light on the benefit side of that question.

Following e g Backhaus et al [1], we assume that the quality of the EPCs plays an important role for their impact and examine to what extent the expert assessments are influenced by the characteristics of the firms and experts that are providing them. Doing so, we correct for the possible influence caused by resident characteristics and some housing attributes that are not taken into account by the certificates.

Another issue addressed concerns the possible impact of the EPCS on the selling price. The residential price impact studies that have been undertaken so far seem to point in different directions. For example, Kjaerby [2] concludes that the EPC impact on energy consumption is negligible while a study commissioned by the EU Commission states that an analysis of property transactions in a number of EU countries "overwhelmingly points to energy efficiency being rewarded by the market", see page 12 in Bio Intelligence Service et al [3].

We will analyze both issues by means of a database that has been constructed by matching the Swedish EPCs for single-family houses sold in 2009 and 2010 with additional information about the houses and the residents. The database makes it possible to quantify several characteristic traits of "EPC-firms" and their experts and to describe the energy efficiency in terms of its constituting components rather than as a rating index. Specifically, we will address the following questions.

Are the EPC-assessments of energy consumption and conservation potential related to firm and expert characteristics like the number of employed experts and the number of certificates the responsible expert has issued?

To what extent is the transaction price of a house influenced by the EPC-assessments of energy consumption and conservation, i e by the only energy efficiency components impossible to gain knowledge about without access to an EPC?

\footnotetext{
${ }^{4}$ See Directive 2002/91/EC of 16 December 2002on the Energy Performance of Buildings which was recast and reinforced in 2010, Directive 2010/31/EU.
} 
As far as we know, no other study has related the quality of the EPC-information to the characteristics and experience of the assessors. Wahlström [4] is the only price impact study we have found that makes a proper distinction between the information uniquely provided by the EPCs and the information that potential buyers of a house can obtain by visiting it. We will use the same database but exploit the results concerning the impact of firm and expert characteristics by delimiting our price impact analysis to the observations estimated as least biased.

The rest of the paper is organized as follows. Section two provides a short overview of earlier literature and section three presents our database. Our conceptual framework is described in section four and the regression models and results in section five. Section six summarizes the results and provides some suggestions of how the energy performance certificates can be improved.

\section{Short overview literature}

As a part of a European project on consumer response to energy labels in buildings, Backhaus et al [1] provide recommendations to improve the impact of EPCs. One major proposal is to improve the quality and accuracy by means of improved education for the EPC assessors. The report shows that the trust in the EPC increases with the availability of recommendations to use them and points to the important role the real estate agents have in this respect. In line with that, Klar [5] indicates that the real estate agents are more likely to promote the EPCs among homebuyers the higher their quality and comparability. Two other studies underline the importance of accuracy and reproducibility.

Majcen et al [6] reports systematic differences between energy consumption predicted by the energy label and the actual consumption, and the Buildings Performance Institute Europe [7] estimates that reproducibility related problems are major reasons for inaccuracies.

The cost of energy is a main reason for assuming that the energy related information provided by an EPS will influence the transaction price of a single family house - the less energy a family expects to consume the more of their budget can be used for other purposes. As suggested by Mandell and Wilhelmsson [8], strong environmental concerns might also influence the purchasing decision. Whatever reasons families have for including energy efficiency aspects when buying new homes, knowledge about the impact can mainly be gained in two ways.

One option is to use questionnaires or interviews and ask a sample of residents if their purchasing decision was influenced by the EPC or if their energy consumption has been influenced by the EPC. The alternative to this so called a stated-preference approach is to rely on revealed preferences and try to disentangle the influence of the EPC on observed changes in energy consumption or to analyze if the observed transaction price can be related to the energy performance as described by the EPC.

Amecke [9] follows the first alternative and uses a survey to a sample of German households to find out to what extent the EPCs helped them to incorporate energy efficiency into their home purchase decisions. The results show that about 80 percent of the households were aware of the EPC but that less than half of them trusted the information. As perhaps a consequence of the low level of trust, the EPC was rated as having low relevance in comparison with other sources of information such as for example visits to the house, information from the selling party or from friends. Furthermore, energy efficiency was considered to be much less important as purchasing criteria than attributes like for example the location and the price.

Murphy [10] and Watts et al [11] present similar conclusions. Murphy's study is based upon a survey comparing two samples of Dutch households one of which received an EPC during the property 
transaction and one that did not. Though the main focus is on the adoption of energy conservation measures after the purchase, the results also show that only 10 percent of the households having an EPC stated that it influenced their decision to buy the property. Based upon a questionnaire survey among English homeowners, Watts et al [11] finds that almost 95 percent stated that the EPC had no or a minor influence on the sales price.

Using a revealed preference approach, Kjaerby [2] compares the actual energy consumption for heating between a set of Danish single-family homes that have EPC and a control group that have not. After controlling for the influence from confounding variables, like for example house size and household income, no significant difference in energy consumption is found.

As opposed to these results, most studies relating the actual sales price to different explanatory variables seem to conclude that there is a price premium on "green housing". The most comprehensive one, Bio Intelligence Service et al [3], analyses the price premium for energy efficient housing in five European countries by relating the sales price to energy efficiency and housing attributes like number of bedrooms and location. The premium related to energy efficiency was found to be clear and positive in all countries and regions but Oxford (UK). In for example the Flanders, Belgium the sales price will increase with 4 percent if the energy efficiency is increased one level on the seven-level scale. Analyzing all single-family house sales in California during five years, Kahn and Kok [12] concludes that houses with a green certification label have a price premium of about 2-4 percent. Fuerst et al [13] [14] draw similar conclusions by relating the sales price to the energy efficiency ratings for a large number of dwellings in England and Wales, respectively. Interestingly, the study for Wales indicates that there are no significant discounts for rental dwellings having below average energy performance.

One drawback of the reviewed price impact studies is that they do not consider the underlying components used to define energy efficiency. Hence, it is unclear if the estimated price premium is caused by components that a potential buyer can observe by himself or by components that are uniquely provided by the EPCs. Most people who are considering buying a house will visit it before signing a contract and by so doing, they will probably get information about some, if not all, of its characteristics. Hence the price premium might be caused by the observed characteristics rather than by the certificate's energy efficiency measure which can be looked upon as an index that, fully or partly are based upon the same characteristics. Using a dataset for Sweden, Wahlström [4] includes both "observable" and "non-observable" variables from the EPCs when analyzing their price premium. According to the results, significant price effects are related to the observable energy related attributes but there is no price premium related to the non-observables, i e to the EPC label per se.

\section{The data}

We will use a dataset that is based upon the energy performance certificates, EPC's for all Swedish single-family houses sold in 2009 and 2010. The certificates provide detailed information about the energy consumption, the type of energy and heating system used and attributes such as floor area and type of building. Statistics Sweden has helped us match the certification data with transaction prices, information about the residents and the neighborhood and about some additional housing attributes. The resulting database, which is also used by Hårsman and Wahlström [15] and Wahlström [4], includes about 77,000 single-family houses, approximately 37,000 from 2009 and 40,000 from 2010. 
The EPC-definition of energy consumption equals the number of kilowatt hours ( $\mathrm{kWh}$ ) purchased during the preceding twelve months. It is a partly measured and partly computed quantity. The assessors are for example transforming the quantities used of other kinds of energy than electricity to kWh by means of conversion factors provided by the Swedish Energy Agency. The certificates also include expert assessments of conservation potentials and the corresponding annual cost per kWh saved. By instructions all saving measures suggested, ranging from window strip seals to installations of heat pumps, should be cost-efficient implying that the annual cost of a measure during its economic life time should be lower than the variable energy cost.

For this paper, we have expanded the database with variables indicating the experience and knowledge of the experts and firms responsible for the EPC. The EPC-information identifying the issuing experts and their firms is used to characterize each expert by the number of certificates issued and each firm by the number of experts employed. We have also added a variable indicating if a house for which a certificate is issued has or has not been visited by the responsible expert (firm).

Since no other EPC-based studies of residential energy consumption and conservation, to our knowledge, use this kind of information about the experts and their firms we think it is worthwhile to provide a relatively detailed description of the corresponding variables. A short overview follows of the attributes related the houses and residents.

The EPCs for single-family homes in our database are issued by 308 firms having 843 employed assessors in 2009 and by 316 firms with 807 assessors in $2010 .^{5}$ The distribution of "EPC-firms"," EPCexperts" and issued certificates among firms of different size, is roughly the same in 2009 as 2010.

Table 1 provides the numbers for 2010 when about 39000 EPCs were issued.

Table 1. Percent of EPC firms, experts and issued certificates by number of employed experts in 2010.

\begin{tabular}{lccccccc}
\hline $\begin{array}{c}\text { No of } \\
\text { experts }\end{array}$ & $\begin{array}{c}\text { \% of all } \\
\text { firms }\end{array}$ & $\begin{array}{c}\text { \% of all } \\
\text { experts }\end{array}$ & $\begin{array}{c}\text { \% of total certificates } \\
\text { issued }\end{array}$ & \multicolumn{4}{c}{$\begin{array}{c}\text { Certificates per expert } \\
\text { Mean }\end{array}$} \\
\hline \multicolumn{1}{c}{$(1)$} & $(2)$ & $(3)$ & $(4)$ & $(5)$ & $(6)$ & $(7)$ & $(8)$ \\
\hline 1 & 55 & 21 & 11 & 34 & 7 & 1 & 501 \\
$2-5$ & 35 & 36 & 27 & 46 & 14 & 1 & 601 \\
$6-10$ & 7 & 20 & 23 & 42 & 28 & 1.3 & 121 \\
$11-20$ & 2 & 10 & 14 & 135 & 67 & 2.4 & 523 \\
21 and & 1 & 14 & 24 & 51 & 51 & 13 & 89 \\
more & & & & & & & \\
\hline Total & $100 \%$ & $100 \%$ & $100 \%$ & 40 & 9 & 1 & 601 \\
\hline
\end{tabular}

The average firm is small - 55 percent of all firms are of the one-expert type and 35 percent have between two and five employees. Together these firms employ 57 percent of all experts and issue around 38 percent of all certificates and hence the larger firms around 43 percent of all experts and 62 percent of all certificates. The indicated scale advantage is underlined by column five and six showing that the number of issued EPCs per expert is several times higher for the large than for the small firms. Columns seven and eight makes it clear that this variation between size categories to some extent reflects "productivity" differences within each size category. By way of example, the number of issued certificates ranges from 1 to 601 among the experts working in firms employing 2-5 experts.

\footnotetext{
${ }^{5}$ The EPCs with inconsistent information are not included in our database. Including them would add about 20 firms and 90 experts both years.
} 
As shown by table 2, the differences in experience and number of colleagues within the firm might matter for the assessments of energy consumption and conservation potentials. The mean energy consumption varies between 23036 and $24550 \mathrm{kWh}$ and the mean energy conservation potential between $2893-3850 \mathrm{kWh}$. It is difficult to discern any pattern but it seems clear that the relative variation across size classes is smaller for the consumption than for the conservation assessments the corresponding percentage differences are 8 and 33 percent, respectively.

Table 2. Assessment of energy consumption, energy conservation, percentage share of houses visited and of houses considered not to have any potential for conservation by firm size in 2010 .

\begin{tabular}{lcccc}
\hline $\begin{array}{l}\text { No of } \\
\text { experts in } \\
\text { firms }\end{array}$ & $\begin{array}{c}\text { Mean energy } \\
\text { consumption per } \\
\text { certificate kWh }\end{array}$ & $\begin{array}{c}\text { Mean conservation } \\
\text { potential per } \\
\text { certificate kWh }\end{array}$ & $\begin{array}{c}\text { Mean \% of } \\
\text { assessments with 0 } \\
\text { conservation } \\
\text { potential }\end{array}$ & $\begin{array}{c}\text { Mean \% absent } \\
\text { during the } \\
\text { assessment }\end{array}$ \\
\hline 1 & 24,550 & 3,850 & 40 & 17 \\
$2-5$ & 23,786 & 3,747 & 41 & 13 \\
$6-10$ & 23,636 & 3,610 & 21 & 8 \\
$11-20$ & 23,633 & 2,893 & 36 & 13 \\
21 and above & 23,036 & 3,639 & 39 & 47 \\
\hline Mean & 23,709 & 3,575 & 33 & 15 \\
\hline
\end{tabular}

The table also shows percentage of houses assessed not to have any potential for conservation and the percentage visited by the expert before issuing the certificate. In most size classes around or close to 40 percent are classified as lacking potential for energy conservation but the fraction is much lower, 21 percent for the firms having 6-10 employees. One would expect a correlation between these numbers and the percentage of houses visited because the experts are recommended to visit any house for which they suggest conservation measures. The underlying data support this expectation since the correlation is 0.54 between the variables indicating if a house has or has not a conservation potential and if it has or has not been visited. Furthermore, the mean conservation potential conservation potential is about 15 times larger among the houses that have been visited than among other houses ( $4130 \mathrm{kWh}$ and $230 \mathrm{kWh}$ respectively).

We do not know to what extent the variation exemplified in table 2 depends upon policy differences between firms of different sizes, upon differences in experience among their experts or if it simply mirrors differences between the houses assessed. The relationship to the characteristics of the houses and residents will be analyzed in the next section but table 3 indicates that the experience of the experts may play a role for their assessments as well as for their likelihood to suggest conservation measures and visit the houses.

Table 3. Assessment of energy consumption, energy conservation, percentage share of houses visited and of houses considered not to have any potential for conservation by number of issued certificates in 2010

\begin{tabular}{lcccc}
\hline $\begin{array}{l}\text { Certificates } \\
\text { issued by } \\
\text { expert }\end{array}$ & $\begin{array}{c}\text { Mean energy } \\
\text { consumption } \\
\text { kWh }\end{array}$ & $\begin{array}{c}\text { Mean } \\
\text { conservation } \\
\text { potential kWh }\end{array}$ & $\begin{array}{c}\text { Mean \% of } \\
\text { assessments with } 0 \\
\text { conservation } \\
\text { potential }\end{array}$ & $\begin{array}{c}\% \text { absent during } \\
\text { the assessment }\end{array}$ \\
\hline Less than 50 & 24,000 & 3,625 & 26 & 7 \\
$50-100$ & 24,086 & 4,159 & 17 & 1 \\
$101-300$ & 23,625 & 3,773 & 20 & 6 \\
More than 300 & 23,080 & 2,630 & 40 & 42 \\
\hline
\end{tabular}


Like in table 2, the relative variation is smaller for the consumption than for the conservation assessments, 23 080-24 $000 \mathrm{kWh}$ or 4 percent as compared to $2630-4159 \mathrm{kWh}$ or 58 percent. Table 3 , also indicates significant differences between the most experienced assessors, i e those issuing more than $\mathbf{3 0 0}$ certificates, and the others in almost all respects. They have lower assessments of both energy consumption and conservation, they rate 40 percent of the houses to lack conservation potentials and they issue 42 percent of their certificates without visiting the house.

Turning to the characteristics of the assessed houses and their residents, table 4 presents the main housing attributes related to the energy performance and table 5 the demographic and socioeconomic characteristics of the residents and their neighborhood. Appendix table A1 shows additional variables, as for example lot size. As already reported, the average energy consumption is $23,700 \mathrm{kWh}$ per year. If the residents were to implement all the suggested energy saving measures the average energy consumption would decrease with $3600 \mathrm{kWh}$ or by 15 percent.

Table 4. Main housing characteristics related to energy performance from EPC and other sources

\begin{tabular}{|c|c|c|c|c|c|}
\hline Source & Variables & Mean & St.D & Min & Max \\
\hline \multirow[t]{31}{*}{ EPC } & Total energy consumption, KWh per year & 23,709 & 9,707 & 852 & 118,95 \\
\hline & & & & & 6 \\
\hline & $\begin{array}{l}\text { Total energy conservation potential, KWh per } \\
\text { year }\end{array}$ & 3,575 & 5,692 & 0 & 76,730 \\
\hline & Heated floor area, sqm & 166 & 57 & 25 & 900 \\
\hline & Average number of frost days per year & 108 & 35 & 60 & 231 \\
\hline & Period of construction \% & & & & \\
\hline & 1900 or earlier & 2 & & & \\
\hline & $1901-1920$ & 7 & & & \\
\hline & 1921-1940 & 12 & & & \\
\hline & $1941-1960$ & 16 & & & \\
\hline & 1961-1970 & 17 & & & \\
\hline & 1971-1980 & 25 & & & \\
\hline & 1981-1990 & 10 & & & \\
\hline & $1991-2000$ & 5 & & & \\
\hline & 2001 or later & 5 & & & \\
\hline & Type of house (\%) & & & & \\
\hline & Semi-detached & 12 & & & \\
\hline & Duplex & 10 & & & \\
\hline & Detached & 78 & & & \\
\hline & Sources of energy (\%) & & & & \\
\hline & Only electricity & 20 & & & \\
\hline & Only district heating & 13 & & & \\
\hline & Only ground sourced heat pump & 9 & & & \\
\hline & Only water/air/waste air heat pump & 8 & & & \\
\hline & Only biofuels & 5 & & & \\
\hline & Electricity \& (any type of) heat pump & 15 & & & \\
\hline & Electricity \& wood & 8 & & & \\
\hline & $\begin{array}{l}\text { Electricity, biofuels and (any type of) heat } \\
\text { pump }\end{array}$ & 6 & & & \\
\hline & Electricity \& biofuels & 2 & & & \\
\hline & Electricity \& oil-fired boiler & 1 & & & \\
\hline & Other type of energy or energy combination & 15 & & & \\
\hline
\end{tabular}




\begin{tabular}{|c|c|c|c|c|c|}
\hline \multirow{12}{*}{ Other } & \multicolumn{5}{|l|}{ Ventilation Systems (\%) } \\
\hline & $\begin{array}{l}\text { Ventilation type FTX; waste air used for } \\
\text { heating supply air }\end{array}$ & 8 & & & \\
\hline & Ventilation type F; waste & 16 & & & \\
\hline & Ventilation type FT; both waste and supply & 2 & & & \\
\hline & Ventilation type with recycling & 5 & & & \\
\hline & Ventilation type natural draft and others & 69 & & & \\
\hline & \multicolumn{5}{|l|}{ Other housing attributes } \\
\hline & House price, KEUR & 257 & 191 & 0.353 & 4117 \\
\hline & New façade 2003 or later (\%) & 1 & & & \\
\hline & New roof 2003 or later (\%) & 3 & & & \\
\hline & Simple type of windows (\%) & 3 & & & \\
\hline & Two or more bath rooms (\%) & 31 & & & \\
\hline
\end{tabular}

The average heated area is 166 square meters and 78 percent of the houses are of the detached kind. As also shown by table 4, most buildings are quite old and less than 20 percent are constructed after 1980. Since Sweden have rather cold winters compared to for example Germany and Great Britain and the climate varies significantly between is northern and southern areas the local climate plays an important role for the energy consumption. The number of local frost days per year ranges between 60 and 231 and the average is 108 days $^{6}$.

Electricity followed by district heating are the most common sources of energy used for heating and cooling -19.7 and 12.6 percent respectively. It is also noteworthy that more than a third of the houses have some kind of heat pump and that 69 percent use natural draft for ventilation purposes. The last rows of table 4 shows the energy related housing attributes added when Statistics Sweden matched the EPCs with data of their own. Most importantly, the first variable shows that the average sales price of a house is 257,000 Euro.

According to table 5, the average household size is 2.3 and the median income 66,286 Euro per year. The average neighborhood (parish) population density is 405 persons per square kilometer and 16 percent of the population has a foreign background.

Table 5. Main characteristics of households and neighborhood

\begin{tabular}{lcccc}
\hline & Mean & St. D. & Min & Max \\
\hline Household characteristics & & & & \\
Age (Household head) & 55 & 16.32 & 14 & 105 \\
Household size (no. of residents) & 2.30 & 1.30 & 1 & 10 \\
Median disposable income(Household head), EUR per year & 66,286 & 57,652 & & 352,871 \\
Non-Swedish ethnic background (\%) & 16 & & & \\
Neighborhood characteristics & & & & \\
Parish income (median), EUR & 27,622 & 3,512 & 6,156 & 37,593 \\
Population with foreign background \% & 17 & 9 & 4 & 52 \\
Parish density (population/sqkm) & 405 & 789 & 0.21 & 13,234 \\
\hline
\end{tabular}

${ }^{6}$ Means for the years 2004-2008 based on data from the Swedish Meteorological and Hydrological Institute. 


\section{Conceptual framework}

Figure 1 represents the conceptual framework we will use for analyzing the quality of the energy performance certificates, EPC's. The assessments of energy consumption and conservation potential are based upon various attributes of the building and the local climate. As indicated by the upper box, they are also assumed to depend upon characteristics related to the firms and experts who have made the assessments. The assessors do not have any information about the residents but since the consumption assessments are mainly based upon measurements it has to be influenced by e $g$ the size of the family living in the house. The conservation assessments are based on calculations only and we have equivalently assumed that they do not depend upon resident characteristics.

Furthermore, and partly based on empirical evidence provided by Wahlström and Hårsman [15] we assume that the calculated saving potential depends upon the assessed energy consumption.

Figure 1. Factors influencing the expert assessments of energy consumption and saving potential

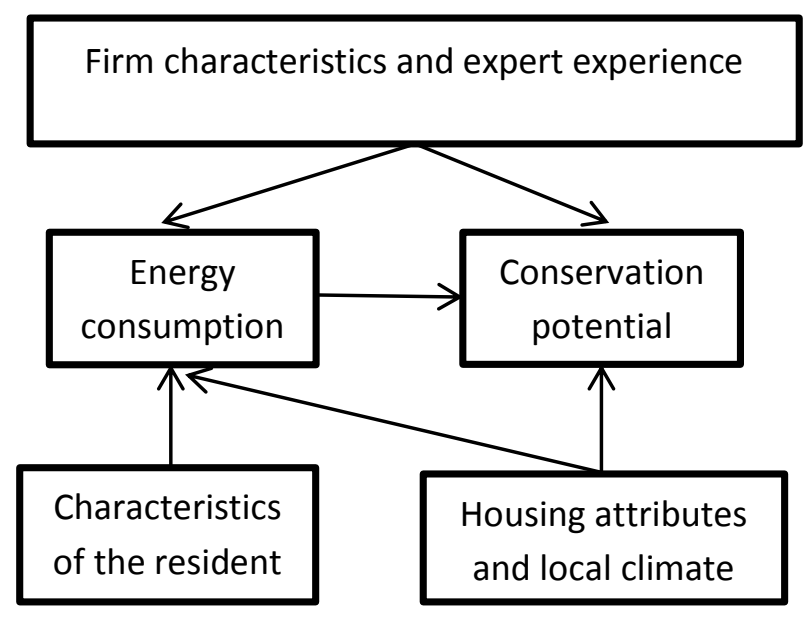

The assessments of energy consumption and conservation potential provided by a certain expert for certain house can be looked upon as consisting of the corresponding "true" values plus an error term related to her and her employers experience and knowledge. There is of course no information available concerning the error terms - we do not know if they are biased or unbiased and if the experts and firms differ in this respect. But we do know that the responsible energy experts differ in terms of e $\mathrm{g}$ employer and frequency of making assessments. As a consequence two or more experts might arrive at different results even if they (in an experimental setting) were to assess identical houses. The more frequently they disagree and the larger the disagreements, the more serious the resulting quality problem.

The degree of inter-rater reliability can be quantified by including our measures of firm and expert characteristics when analyzing the variation in energy consumption and saving potential among different houses. This will be done by means of the models described by equations (1) and (2).

Energy $=f($ Household, House, Firm, Experience $)+u$

Conservation $=\mathrm{g}$ (Energy, House, Firm, Experience) $+\mathrm{w}$

In equation (1), the energy consumption assessment is expressed as a function of the characteristics of the resident, the attributes of the house (including local climate), firm characteristics and the experience of the responsible expert. The error term is denoted by $u$. Correspondingly, equation (2) 
relates the assessed conservation potential to the assessed energy consumption, the attributes of the house, firm characteristics and the expert's experience plus the error term $\mathrm{w}$. In the next section, regression analysis will be used to test the following propositions. Doing so, we will also control for the housing attributes added when matching the EPCs with other sources of information, e $g$ the window quality and the family size.

a) The assessments of energy consumption and energy conservation potential differ systematically between the responsible firms and experts.

b) These inter-rater problems will be smaller for the energy consumption than for the energy conservation assessment since the former are largely based upon measurements rather than computations.

Figure 2, which corresponds to the model used by Wahlström [4], relates the contract price of a house to the energy consumption and saving potential, to its energy related and other attributes and to its neighborhood.

Figure 2. Factors influencing the contract price of housing

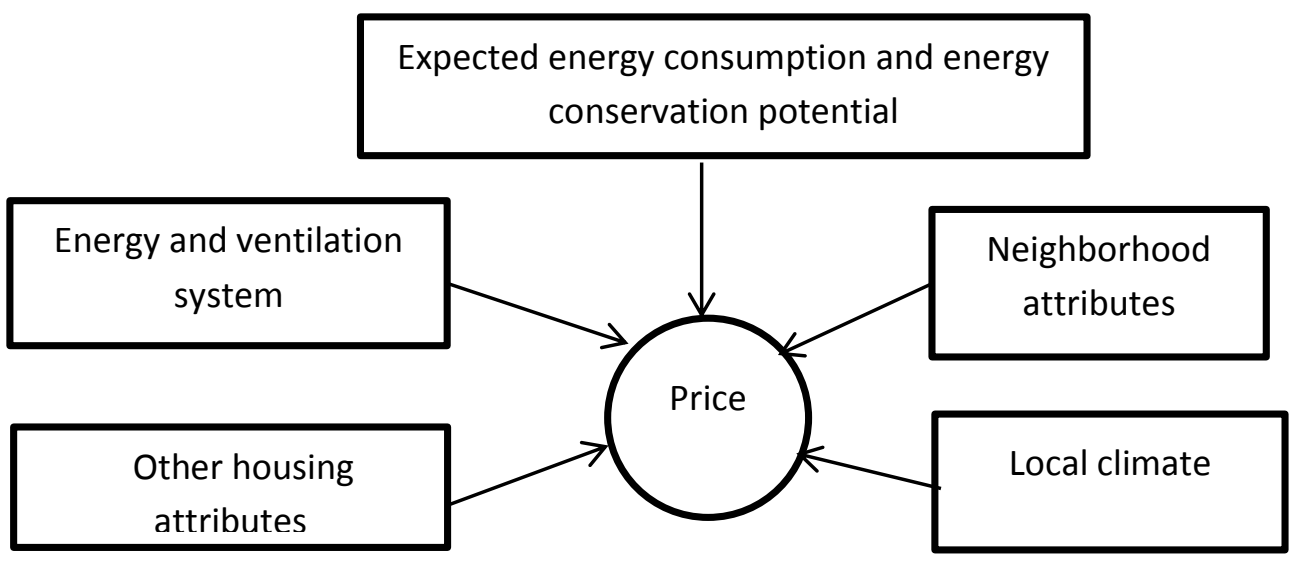

Most, if not all buyers of a house will visit and inspect it before taking a decision. Doing so, they can at least in principle judge all but two of the explanatory factors indicated by figure $\mathbf{2}$. Without having an energy performance certificate they will not know the expert assessments of energy consumption and saving potential. By analyzing if any of these two variables influences the price we can hence find out if the EPCs have an impact.

The model given by equation (3) will be used as a starting point for analyzing the relationship between the sales price of a house and the explanatory variables outlined in figure 2 .

Price $=\mathrm{h}$ (Energy, Conservation, System, Other, Neighborhood, Climate) $+\mathrm{v}$

When estimating this model we will exploit the results concerning inter-rater reliability. This will be done by sorting out EPCs made by the firms responsible for the largest over- or under-estimates of energy consumption and conservation. We will follow Wahlström [4] to handle the problem caused by the difference between expected and assessed energy consumption. Since any buyer of a house will have less income left over for other consumption after paying his energy bill it seems likely that he will be willing to pay more for the house the less energy he expects to consume. However, we do not know to what extent, if any the expected energy consumption is related to the assessed energy consumption provided by the energy performance certificate. As an alternative a buyer might 
consider the difference between the assessed energy consumption and conservation potential when forming his expectations. The reason for doing so is that all the saving measures suggested by an expert have to be cost effective according to the EPC-instructions. Therefore, rational buyers are likely to implement them and focus on the remaining part of the assessed energy consumption when forming their expectations. It should be noted that the ignorance concerning expectation will cause corresponding problems when analyzing the price premium of energy efficiency ratings or green label classifications, because the observed (or computed) energy consumption constitutes the major variable in all labelling schemes, see Pérez-Lombard et al [16].

Considering these arguments and earlier literature and focusing on the energy related variables the following propositions will be tested when estimating equation (3).

c) The assessed energy consumption has a negative or a not significant influence on the transaction price

d) The difference between the energy consumption and the conservation potential has a negative or a not significant impact on the price.

e) Housing attributes increasing the thermal quality of the house will increase its price. Differences in the heating system as well as ventilation systems will also have significant effects on house prices.

\section{Regression models and results}

Ordinary least square regressions (OLS) are applied to estimate equations (1) - (3). The results reported in this section are focused on testing the hypotheses concerning inter-rater reliability and price impact of EPC assessments, but all the estimated coefficients are reported in appendix tables A2-A4. In order to control for autocorrelation of the error term for houses assessed by the same firm, all regressions have been adjusted for cluster effects.

\subsection{The quality impact of firm and expert characteristics}

As reported in table 6, several variants of model (1) are estimated. The first column presents the results when relating the assessed energy consumption to the housing attributes provided by the EPCs and the variables indicating firm and expert characteristics. In the second column the housing variables from other sources and the resident characteristics are added as explanatory variables. The same goes for column three but here each firm is represented by a dummy variable in order to capture the size effect as well as unobservable firm differences.

A comparison between columns (1) and (2) shows that the estimated coefficients related to firm and expert characteristics are about the same and that the explanatory power only increases marginally, from 52.1 to 54 percent, when adding the variables not included in the EPC. As shown in table A2, the added variables have statistically significant coefficients, but they are too small to influence the other estimates. Table A2, also shows, as expected, that the energy consumption is strongly influenced by housing attributes included in EPC such as e $g$ heated floor area and heating system. By way of example, a 10 percent larger heated floor area implies an increase in energy consumption with 6 percent.

Columns (1) and (2) in table 6 also show that the estimates of energy consumption are almost unaffected by firm size and firm policy on visiting houses for assessment purpose. The one exception is the firm category having 6-10 employed experts. The estimated coefficient for this size category, - 
0.024, corresponds to a 3 percent lower estimate of energy consumption than for the category used as reference, that is the firms having only one expert ${ }^{7}$. Since there are no significant differences for the other size categories, it seems as if the quality problem caused by lack of inter-rater reliability is quite small and in practice unrelated to the housing and resident characteristics not included in the EPCs.

Table 6. Estimated impact of firm and expert characteristics on the assessed energy consumption. The dependent variable is the logarithm (In) of the energy consumption.

\begin{tabular}{|c|c|c|c|}
\hline VARIABLES & $\begin{array}{l}\text { EPC variables } \\
\text { only }\end{array}$ & $\begin{array}{l}\text { EPC variables and } \\
\text { other controls }\end{array}$ & $\begin{array}{l}\text { Individual firm } \\
\text { effects }\end{array}$ \\
\hline & (1) & $(2)$ & (3) \\
\hline \multirow[t]{2}{*}{ Firms with 2-5 experts } & -0.017 & -0.015 & \\
\hline & $(0.013)$ & $(0.013)$ & \\
\hline \multirow[t]{2}{*}{ Firms with 6-10 experts } & $-0.030 * *$ & $-0.024^{*}$ & \\
\hline & $(0.015)$ & $(0.015)$ & \\
\hline \multirow{2}{*}{ Firms with $11-20$ experts } & -0.010 & -0.005 & \\
\hline & $(0.017)$ & $(0.018)$ & \\
\hline \multirow[t]{2}{*}{ Firms with more than 21 experts } & -0.004 & -0.004 & \\
\hline & $(0.011)$ & $(0.010)$ & \\
\hline \multicolumn{2}{|l|}{$\begin{array}{l}\text { Energy consumption interval in } \mathrm{kWh} \text { for } \\
80 \% \text { of the firms }\end{array}$} & & $19200-28800$ \\
\hline \multirow[t]{2}{*}{$\%$ firm presence } & -0.000 & -0.000 & \\
\hline & $(0.000)$ & $(0.000)$ & \\
\hline \multirow{2}{*}{$\begin{array}{l}\text { No of certificates assessed by expert } \\
\text { (In) }\end{array}$} & 0.002 & 0.001 & 0.005 \\
\hline & $(0.003)$ & $(0.003)$ & $(0.003)$ \\
\hline No of observations & 75,726 & 68,948 & 68,948 \\
\hline R-squared & 0.521 & 0.54 & 0.55 \\
\hline \multicolumn{4}{|c|}{$\begin{array}{l}\text { Standard errors clustered by EPC firms in parentheses }{ }^{* * *} p<0.01,{ }^{* *} p<0.05,{ }^{*} p<0.1 \\
\text { The reference group is one-expert firms in column } 1 \text { and } 2 \text { and one firm having } 15 \text { employees in column } 3\end{array}$} \\
\hline \multirow{8}{*}{\multicolumn{4}{|c|}{$\begin{array}{l}\text { However, large and systematic firm effects are found when we consider individual firm effects rather } \\
\text { than only the effect caused by their size. In this regression, the estimated coefficient for each one of } \\
\text { some } 300 \text { firms indicates the difference vis-a-vis a reference firm with } 15 \text { employees which has } \\
\text { assessed about } 6 \text { percent of all the houses. It turns out that the percentage difference in assessed } \\
\text { energy consumption deviates more than } 20 \text { percent upwards or downwards for about } 20 \text { percent of } \\
\text { all firms. As shown in table } 6 \text {, the variation is also large among the remaining } 80 \text { percent of the firms. } \\
\text { If the reference firm has assessed the energy consumption to be } 24000 \mathrm{kWh} \text { for a house, the } \\
\text { assessments for similar houses made by the other firms would range between } 19200 \text { and } 28800 \\
\text { kWh. }\end{array}$}} \\
\hline & & & \\
\hline & & & \\
\hline & & & \\
\hline & & & \\
\hline & & & \\
\hline & & & \\
\hline & & & \\
\hline \multicolumn{4}{|c|}{$\begin{array}{l}\text { The variable indicating the likelihood that a firm will visit the houses they are assessing remains } \\
\text { insignificant in all three regressions which seems a little surprising. If one assumes that the energy } \\
\text { consumption as well as the probability of visiting is lower for new than for old houses, one would } \\
\text { expect the likelihood of visits to have a significant negative impact. Hence the result might indicate } \\
\text { that the firms are as likely to inspect new as old houses. That the variable measuring the experience }\end{array}$} \\
\hline
\end{tabular}

\footnotetext{
${ }^{7}$ The percentage difference associated with being in the respective category is calculated as (100 (exp(b)-1)
} 
of the experts is insignificant in all regressions might reflect that their tendency to over- or underestimate the "true" energy consumption is unrelated to their experience.

All in all, these results point to existence of quite severe inter-rater reliability problem as suggested by proposition a), which however are only partly explained by firm size and visits but mainly by unobserved firm characteristics.

The estimation of model (2) was implemented with a similar procedure, i.e. we first relate the assessed energy conservation potential to the energy consumption and the housing attributes included in the certificates and then add housing variables from other sources. EPC firm characteristics as well as expert experience are included in both models. In addition to controlling for firm size and visits, we have included a variable capturing the frequency of EPCs lacking conservation assessments for each responsible firm.

The main results corresponding to the models without and with housing characteristics from other sources than EPC are shown in column (1) and (2) of table $7^{8}$. In contrast to estimates of model (1) all regression variants show that the firm characteristics have a significant influence on the assessed conservation potential.

Table 7. Estimated impact of firm and expert characteristics on the assessed energy conservation potential. The dependent variable is the logarithm (In) of the energy conservation.

\begin{tabular}{|c|c|c|c|}
\hline VARIABLES & $\begin{array}{l}\text { EPC variables } \\
\text { only }\end{array}$ & $\begin{array}{l}\text { EPC variables and } \\
\text { other controls }\end{array}$ & $\begin{array}{l}\text { Individual firm } \\
\text { effects }\end{array}$ \\
\hline & (1) & $(2)$ & (3) \\
\hline Firms with 2-5 experts & $\begin{array}{c}-0.894 * * * \\
(0.278)\end{array}$ & $\begin{array}{c}-0.904^{* * *} \\
(0.279)\end{array}$ & \\
\hline Firms with 6-10 experts & $\begin{array}{c}-1.185^{* * *} \\
(0.301)\end{array}$ & $\begin{array}{c}-1.190 * * * \\
(0.302)\end{array}$ & \\
\hline Firms with $11-20$ experts & $\begin{array}{c}-2.390 * * * \\
(0.314)\end{array}$ & $\begin{array}{c}-2.397^{* * *} \\
(0.315)\end{array}$ & \\
\hline Firms with more than 21 experts & $\begin{array}{l}-1.781 * * * \\
(0.315)\end{array}$ & $\begin{array}{c}-1.787^{* * *} \\
(0.315)\end{array}$ & \\
\hline $\begin{array}{l}\text { Energy consumption interval in } \mathrm{kWh} \\
\text { for } 80 \% \text { of the firms }\end{array}$ & & & $600-5400$ \\
\hline$\%$ firm presence & $\begin{array}{c}0.050 * * * \\
(0.006)\end{array}$ & $\begin{array}{c}0.050 * * * \\
(0.006)\end{array}$ & \\
\hline$\% 0$ saving assessment by firm & $\begin{array}{c}-0.066 * * * \\
(0.008)\end{array}$ & $\begin{array}{c}-0.066^{* * *} \\
(0.008)\end{array}$ & \\
\hline $\begin{array}{l}\text { No of certificates assessed by expert } \\
\text { (In) }\end{array}$ & $0.118^{* *}$ & $0.119 * *$ & -0.008 \\
\hline & $(0.057)$ & $(0.057)$ & $(0.056)$ \\
\hline No of observations & 75,726 & 75,261 & 75,261 \\
\hline R-squared & 0.466 & 0.467 & 0.493 \\
\hline \multicolumn{4}{|c|}{$\begin{array}{l}\text { Standard errors clustered by EPC firms in parentheses }{ }^{* * *} p<0.01,{ }^{* *} p<0.05,{ }^{*} p<0.1 \\
\text { The reference group is one-expert firms in column (1) and (2) and one firm having } 15 \text { employ }\end{array}$} \\
\hline $\begin{array}{l}\text { The relationships to firm size categori } \\
\text { that the added housing attributes play }\end{array}$ & $\begin{array}{l}\text { are almost ident } \\
\text { minor role. The }\end{array}$ & $\begin{array}{l}\text { cal in column (1) an } \\
\text { stimated coefficien }\end{array}$ & $\begin{array}{l}\text { hich indicates } \\
\text { rms having } 11-20\end{array}$ \\
\hline
\end{tabular}


employees is about 90 percent lower as compared to the reference category, i e one expert firms. The corresponding differences are also significant for the rest of the firms - their assessments are 20 to 80 percent lower.

In addition to the firm size effects, the results point to the importance of visiting the houses for assessment purposes. On average firms having a one percent higher likelihood of visiting a house assess the conservation potential to be 5 percent higher.

The frequency of assessments not suggesting any conservation measures is significant and negative firms having a one percent higher likelihood of assessing no saving possibility will on average produce 6- 7 percent lower assessments of the conservation potential. Though almost self-evident, the result points to the perhaps more interesting question of why some firms suggest conservation measures more often than others.

The results are further supported by column (3) when individual firms are compared with a reference firm that has 15 employees and is responsible for about six percent of all assessments. Considering similar houses about 20 percent of the firms assesses the conservation potential to be 80 percent lower or higher than suggested by the reference firm. Hence the percentage differences caused by individual firm effects are about four times bigger for the conservation assessments than for the energy consumption assessments. Expressed in another way, 80 percent of the firms will make conservation assessments ranging between 600 and $5400 \mathrm{kWh}$ for a house that according to the reference firm has a conservation potential equal to $3000 \mathrm{kWh}$.

The estimates related to expert experience, as measured by the number of certificates assessed yearly, are also significant and of the same magnitude as shown by columns (1) and (2). However, the effect turns insignificant when representing each individual firm as in column (3). One possible explanation is that the individual firm effects also capture the experiences of the experts.

It should be also noted that we have also estimated regressions for houses with above zero saving potential only, thereby excluding extreme cases. The results are rather similar though the coefficient estimates are somewhat smaller.

Turning to the impact of housing attributes, our results suggest that about half of the variation in conservation potential estimates is explained by housing attributes provided by the EPC. The estimates of housing variables from other sources are statistically significant but their effect is rather small and they don't add much to the explanatory power of the model.

By and large, our results support proposition a), i.e. the differences in assessment of energy consumption and conservation potential differ systematically between firms. We have found significant variation in firm effects while estimating energy consumption and conservation potential. At the same time we found no practically significant differences caused by experts' experience.

Proposition b) is also supported since our results show that firm effects are much stronger for the assessments of energy conservation potential as compared to the energy consumption assessments.

Additionally, the results indicate that the quantitative impacts of adding housing attributes not included in the EPC and resident characteristics are too small to influence the outcome when testing propositions $a$ ) and $b$ ).

We conclude that the quality of the EPCs can be improved substantially by implementing policy measures able to reduce the inter-rater reliability problem. 


\subsection{Price impact}

We have used model (3) to test our hypotheses regarding the impact of energy consumption and conservation potential on the contract price. The full results of OLS estimations ${ }^{9}$ are presented in table A4. Table 8 shows the results that are most important for judging if the energy consumption and conservation assessments play a significant role. In the table, columns (1) and (2) show the price impact of the energy consumption, and column (3) and (4) the impact of the absolute difference between the energy consumption and energy conservation, i e expected consumption after improvements. The idea is to test different ways to capture the buyers' expectations concerning energy consumption. To exploit our results concerning inter-rater reliability we have simply excluded all assessments made by the firms whose assessments are estimated to deviate more than 20 percent from the reference firm. The results are shown in column (2) and (4) with a somewhat smaller estimation sample. All EPC characteristics as well as other control variables are accounted for in columns (1)-(4) $)^{10}$.

Table 8. The estimated impact of energy consumption and conservation and other housing attributes on the transaction price. The dependent variable is the logarithm $(\mathrm{In})$ of the transaction price.

\begin{tabular}{lcccc}
\hline VARIABLES & $(1)$ & $(2)$ & $(3)$ & $(4)$ \\
\hline Energy Consumption $(\mathrm{In})$ & $0.068^{* * *}$ & $0.066^{* * *}$ & & \\
Expected consumption after improvements $(\mathrm{In})$ & $(0.006)$ & $(0.006)$ & & \\
& & & $0.067 * * *$ & $0.075^{* * *}$ \\
Construction period 1941-1960 & $-0.495^{* * *}$ & $-0.495^{* * *}$ & $-0.487^{* * *}$ & $-0.488^{* * *}$ \\
& $(0.008)$ & $(0.008)$ & $(0.008)$ & $(0.008)$ \\
Heated floor area sqm (In) & $0.435^{* * *}$ & $0.435^{* * *}$ & $0.439^{* * *}$ & $0.435^{* * *}$ \\
& $(0.006)$ & $(0.006)$ & $(0.006)$ & $(0.006)$ \\
Only district heating & $0.083^{* * *}$ & $0.083^{* * *}$ & $0.070^{* * *}$ & $0.068^{* * *}$ \\
& $(0.005)$ & $(0.005)$ & $(0.005)$ & $(0.005)$ \\
Ventilation type FTX & $0.055^{* * *}$ & $0.057^{* * *}$ & $0.054^{* * *}$ & $0.055^{* * *}$ \\
& $(0.005)$ & $(0.005)$ & $(0.005)$ & $(0.005)$ \\
\hline No of observations & 69,698 & 67,961 & 68,926 & 67,244 \\
R-squared & 0.761 & 0.759 & 0.762 & 0.760 \\
\hline Robust standard errors in parentheses *** $\mathrm{p}<0.01, * * p<0.05, * \mathrm{p}<0.1$ & & &
\end{tabular}

Robust standard errors in parentheses $* * * p<0.01, * * p<0.05, * p<0.1$

In line with Wahlström [4], column (1) shows a positive relationship between energy consumption and house price, indicating that the transaction price will be higher the higher the energy consumption. As shown by column (2) the result only changes marginally after excluding the assessments made by firms deviating more than 20 percent from the reference firm in terms of the assessments. Though significant, the magnitude of the estimate is rather small - a 10 percent increase in consumption will increase the price by about 0.7 percent.

The positive sign is of course counterintuitive since one would expect rational buyers to pay a lower and not a somewhat higher price for houses with having higher assessed energy consumption. However, the energy consumption assessments do not necessarily reflect the buyers' own

\footnotetext{
${ }^{9}$ We have even tried instrumental variable regressions since energy consumption is not completely exogenous. Instrumenting energy consumption by the number of households and their ethnical background, which are correlated to energy consumption but not house price, we found identical results.

${ }^{10}$ Variance Inflation Factor (VIF) test on multicollinearity of regressors suggested no severe problems in using energy consumption estimates and other regressors together.
} 
expectations. A rational buyer may for example pay more attention to the energy consumption resulting after implementing the saving measures suggested by experts. This is tested in column (3) and (4) but the result is still counterintuitive. We cannot explain this anomaly, but it may be related to some unobservable housing attribute that influences the price and the energy consumption in the same direction. It may of course also reflect that a more sophisticated model is needed to capture the expected energy consumption - it is evidently not enough to simply subtract the assessed conservation potential from the assessed energy consumption.

Turning to the attributes a buyer can observe by visiting the house, table A4 shows that all the characteristics that a buyer can observe by visiting the house have a significant and rather strong influence on the contract price. As exemplified in table 8 the price of a house will decrease with 40 percent if constructed in 1941-1960 as compared to after 2001, it will increase with about 4 percent if the heated floor area increases with 10 percent, with 8-9 percent if linked to district heating rather than using electricity only and with 5-6 percent if having the most efficient ventilation system. All other housing attributes as well as the neighborhood characteristics are significant and have expected signs. All in all, the explanatory variables included in the model explain about $76 \%$ of the observed price variation.

Although our results do not lend support to propositions $\mathrm{c}$ ) and d) and suggest significant though small positive relationship between transaction price and energy consumption, they seem to rule out the claim that a higher EPC energy efficiency rating will result in a higher price.

At the same time, proposition e) on price premium caused by observable housing attributes such as thermal quality, heating and ventilations systems is fully supported by our results pointing to the superior role played by observable energy related house characteristics as compared to EPC estimates.

\section{Summary and conclusions}

This paper presents new knowledge concerning the quality and impact of energy performance certificates for the residential sector. Specifically, the following two questions are investigated. To what extent are the energy consumption and energy conservation assessments provided by the EPCS influenced by characteristics related to the assessors and their firms? Do the performance certificates matter for the observed transaction prices? We try to answer the questions by applying regression analysis to a database that has been created by matching the Swedish EPCs for single family houses sold in 2009 and 2010 with additional information about the houses and the residents.

The database includes 37000 houses in 2009 and 40000 in 2010. Both years the EPCs were issued by around 300 firms and 800 experts. The quality issue is framed in terms of inter-rater reliability which means that we analyze if different experts arrive at the same conclusions when assessing houses that have identical attributes regarding e g heated area, vintage, heating system and local climate. The results show that it matters quite a lot which firm and expert is responsible for the assessments. Excluding the extremes, the variation around the firm used as a point of reference is $+/-20$ percent for the energy consumption assessments and $+/-80$ percent for the assessed energy conservation potentials. Most of the variation is caused by unobservable characteristics but the conservation potential is also influenced by the size of the firm. 
Several earlier studies report a price premium for houses labelled as energy efficient. However, it is unclear whether the premium is related to the label per se or to attributes that any potential buyer of a house can observe by visiting it. Like Wahlström [4], we have made a separation between the assessments of energy consumption and conservation, which are uniquely provided by the EPC and other housing attributes. Doing so and exploiting our results concerning the reliability of the assessments, it turns out the price effect is small and significant. However, the price is higher the higher the assessed energy consumption, an anomaly we cannot explain. It may be due to some unobservable housing attributes influencing the price and the expected consumption in the same direction. It may also be caused by differences between the assessed energy consumption and the consumption expected by the buyers.

The variation in assessments across firms and experts may be smaller currently than indicated by our findings for the years 2009 and 2010. However, the magnitude of the related quality problem still calls for policy initiatives aiming at evaluating the assessors and possibly also improving their expert education. Considering the cost of operating the EPC-system and our (negative) findings concerning their price impact, we also think that government agencies as well as the EU-commission should initiate additional studies focused on identifying and estimating the benefits of the system. Additionally, the agencies responsible for the EPCs should take measures making it easier to match their information with information from other sources such as for example the real estate tax assessments.

As for future research, it seems obvious that more knowledge is needed concerning the causes behind the large differences in assessments provided by different firms and their experts. More research is also needed to disentangle the possible price premium related to the unique EPC-data respectively to housing attributes that can be observed by any potential buyer of a house. If the kind databases that we have used were created and analyzed with some regularity more light could be shed on both issues.

\section{References}

[1] J. Backhaus, C. Tigchelaar and M. de Best-Waldhober, "Key findings and Policy Recommendations to Improve Effectiveness of Energy Performance Certificates and the Energy Performance of Building Directive". 2011. Available from: http://www.idealepbd.eu

[2] V. H. Kjaerby, "Does energy labelling on residential housing cause energy savings?" Proceedings ECEEE Summer Study. 2009. Available from: http://www.eceee.org/library/conference_proceedings/eceee_Summer_Studies/2009/ Panel_3/3.068.

[3] Bio Intelligence Service, "Energy performance certificates in buildings and their impact on transaction prices and rents in selected EU countries". 2013.

[4] M. Wahlström, "Doing good but not that well? A dilemma for energy conserving homeowners," KTH Royal Institute of Technology, Stockholm. WP. 2015.

[5] H. Klar, "Energideklarationen: Uppfyller energideklarationen sitt syfte?" Uppsala University. ISRN UTH-INGUTB-X-B-2014/05-SE. 2014.

[6] D. Majcen, L. C. M. Itard, and H. Visscher, "Theoretical vs. actual energy consumption of labelled dwellings in the Netherlands: Discrepancies and policy implications," Energy Policy, vol. 54, pp. 125-136, Mar. 2013. 
[7] Building Performance Institute Europe, "Energy Performance Certificates across Europe - from design to implementation". 2010.

[8] S. Mandell and M. Wilhelmsson, "Willingness to Pay for Sustainable Housing," J. Hous. Res., Apr. 2011.

[9] H. Amecke, "The impact of energy performance certificates: A survey of German home owners," Energy Policy, vol. 46, pp. 4-14, Jul. 2012.

[10] L. Murphy, "The influence of the Energy Performance Certificate: The Dutch case," Energy Policy, vol. 67, pp. 664-672, Apr. 2014.

[11] C. Watts, M. F. Jentsch, and P. A. James, "Evaluation of domestic Energy Performance Certificates in use," Build. Serv. Eng. Res. Technol., vol. 32, no. 4, pp. 361-376, Nov. 2011.

[12] M. E. Kahn and N. Kok, "The capitalization of green labels in the California housing market," Reg. Sci. Urban Econ., vol. 47, pp. 25-34, Jul. 2014.

[13] F. Fuerst, P. McAllister, A. Nanda, and P. Wyatt, "Does energy efficiency matter to home-buyers? An investigation of EPC ratings and transaction prices in England," Energy Econ., vol. 48, pp. 145-156, Mar. 2015.

[14] F. Fuerst, P. McAllister, A. Nanda, and P. Wyatt, "Energy performance ratings and house prices in Wales: An empirical study," Energy Policy, vol. 92, pp. 20-33, May 2016.

[15] M. H. Wahlström and B. Hårsman, "Residential energy consumption and conservation," Energy Build., vol. 102, pp. 58-66, Sep. 2015.

[16] L. Pérez-Lombard, J. Ortiz, R. González, and I. R. Maestre, “A review of benchmarking, rating and labelling concepts within the framework of building energy certification schemes," Energy Build., vol. 41, no. 3, pp. 272-278, Mar. 2009. 


\section{Appendix}

Table A1. Other housing, household and neighborhood characteristics

\begin{tabular}{lrrrr}
\hline & Mean & St.D. & Min & Max \\
\hline Other housing attributes & & & & \\
Size of property plot, sqm & 1,333 & 3,180 & 52 & 655,055 \\
Open fireplace, electric stove or stove (\%) & 48 & & & \\
Living or recreation room in basement (\%) & 12 & & & \\
Kitchen standard, simple (\%) & 25 & & & \\
Kitchen standard, high (\%) & 8 & & & \\
Kitchen standard, normal (\%) & 67 & & \\
New kitchen equipment 2003 or later (\%) & 5 & & \\
Recently (year 2000 or later) rebuilt or & & & \\
extended (\%) & 3.5 & & & \\
Housing Location (\%) & & & & \\
Private shoreline or beach & 1 & & & \\
0-75 m to shoreline & 2 & & & \\
76-150 m shoreline & 3 & & & \\
150 m and more to shoreline & 95 & & & \\
Other Household Data & & & & \\
Higher Education (Yes/No \%) & 36 & & & \\
At least one "green" car in household (\%) & 5 & & & \\
Other Neighborhood characteristics & & & & \\
Share of votes for the Environmental Party & 6 & 3 & 0.3 & \\
Municipality income tax & 21 & 2 & 17 & \\
Population with Higher Education \% & 13 & 6 & 5 & \\
\hline
\end{tabular}

Table A2. Estimated impact of housing and household characteristics on the assessed energy consumption. The dependent variable is the logarithm (In) of the energy consumption.

\begin{tabular}{lccc}
\hline VARIABLES & $\begin{array}{c}\text { EPC variables } \\
\text { only }\end{array}$ & $\begin{array}{c}\text { EPC and other control } \\
\text { variables }\end{array}$ & $\begin{array}{c}\text { Individual firm } \\
\text { effects }\end{array}$ \\
\hline Construction year 1900 or earlier & $(1)$ & $(2)$ & $(3)$ \\
& $0.189^{* * *}$ & $0.214^{* * *}$ & $0.218^{* * *}$ \\
Construction year 1901-1920 & $(0.013)$ & $(0.013)$ & $(0.013)$ \\
& $0.183^{* * *}$ & $0.200^{* * *}$ & $0.203^{* * *}$ \\
Construction year 1921-1940 & $(0.008)$ & $(0.008)$ & $(0.008)$ \\
& $0.187^{* * *}$ & $0.206^{* * *}$ & $0.207^{* * *}$ \\
Construction year 1941-1960 & $(0.009)$ & $(0.008)$ & $(0.007)$ \\
& $0.155^{* * *}$ & $0.179^{* * *}$ & $0.178^{* * *}$ \\
Construction year 1961-1970 & $(0.007)$ & $(0.007)$ & $(0.006)$ \\
& $0.118^{* * *}$ & $0.148^{* * *}$ & $0.146^{* * *}$ \\
Construction year 1971-1980 & $(0.007)$ & $(0.006)$ & $(0.006)$ \\
& $0.046^{* * *}$ & $0.070^{* * *}$ & $0.072^{* * *}$ \\
Construction year 1981-1990 & $(0.007)$ & $(0.006)$ & $(0.006)$ \\
& $0.022^{* * *}$ & $0.039^{* * *}$ & $0.039^{* * *}$ \\
Construction year 1991-2000 & $(0.007)$ & $(0.007)$ & $(0.007)$ \\
& $0.038^{* * *}$ & $0.043^{* * *}$ & $0.041^{* * *}$ \\
& $(0.010)$ & $(0.010)$ & $(0.009)$ \\
\hline
\end{tabular}




\begin{tabular}{|c|c|c|c|}
\hline Semi-detached house & $\begin{array}{c}-0.023^{* * *} \\
(0.005)\end{array}$ & $\begin{array}{c}-0.034^{* * *} \\
(0.006)\end{array}$ & $\begin{array}{c}-0.037^{* * *} \\
(0.004)\end{array}$ \\
\hline Duplex house & $\begin{array}{c}-0.122^{* * *} \\
(0.006)\end{array}$ & $\begin{array}{c}-0.137 * * * \\
(0.006)\end{array}$ & $\begin{array}{c}-0.144^{* * *} \\
(0.004)\end{array}$ \\
\hline Heated floor area sqm (In) & $\begin{array}{c}0.586 * * * \\
(0.008)\end{array}$ & $\begin{array}{c}0.561^{* * *} \\
(0.007)\end{array}$ & $\begin{array}{c}0.562^{* * *} \\
(0.007)\end{array}$ \\
\hline Electricity \& (any type of) heat pump & $\begin{array}{c}-0.145^{* * *} \\
(0.007)\end{array}$ & $\begin{array}{l}-0.151^{* * *} \\
(0.008)\end{array}$ & $\begin{array}{c}-0.147^{* * *} \\
(0.007)\end{array}$ \\
\hline Only district heating & $\begin{array}{c}0.117^{* * *} \\
(0.011)\end{array}$ & $\begin{array}{c}0.115^{* * *} \\
(0.010)\end{array}$ & $\begin{array}{c}0.117^{* * *} \\
(0.010)\end{array}$ \\
\hline Electricity \& wood & $\begin{array}{c}0.146 * * * \\
(0.012)\end{array}$ & $\begin{array}{c}0.140 * * * \\
(0.011)\end{array}$ & $\begin{array}{c}0.143 * * * \\
(0.012)\end{array}$ \\
\hline Only biofuels & $\begin{array}{c}0.322 * * * \\
(0.009)\end{array}$ & $\begin{array}{c}0.318^{* * *} \\
(0.009)\end{array}$ & $\begin{array}{c}0.333 * * * \\
(0.008)\end{array}$ \\
\hline $\begin{array}{l}\text { Electricity, biofuels and (any type of) } \\
\text { heat pump }\end{array}$ & $\begin{array}{l}-0.006 \\
(0.010)\end{array}$ & $\begin{array}{c}-0.018^{* *} \\
(0.009)\end{array}$ & $\begin{array}{l}-0.013 \\
(0.009)\end{array}$ \\
\hline Electricity \& oil-fired boiler & $\begin{array}{c}0.260 * * * \\
(0.008)\end{array}$ & $\begin{array}{c}0.266^{* * *} \\
(0.008)\end{array}$ & $\begin{array}{c}0.270^{* * *} \\
(0.007)\end{array}$ \\
\hline Only water/air/waste air heat pump & $\begin{array}{c}-0.202^{* * *} \\
(0.008)\end{array}$ & $\begin{array}{c}-0.206 * * * \\
(0.007)\end{array}$ & $\begin{array}{c}-0.202^{* * *} \\
(0.007)\end{array}$ \\
\hline Only ground sourced heat pump & $\begin{array}{c}-0.410 * * * \\
(0.010)\end{array}$ & $\begin{array}{c}-0.417^{* * *} \\
(0.010)\end{array}$ & $\begin{array}{c}-0.408^{* * *} \\
(0.008)\end{array}$ \\
\hline $\begin{array}{l}\text { Combination of electricity and } \\
\text { biofuels }\end{array}$ & $\begin{array}{c}0.309 * * * \\
(0.009)\end{array}$ & $\begin{array}{c}0.300 * * * \\
(0.008)\end{array}$ & $\begin{array}{c}0.301^{* * *} \\
(0.008)\end{array}$ \\
\hline Other types of energy sources & $\begin{array}{c}0.065 * * * \\
(0.007)\end{array}$ & $\begin{array}{c}0.053 * * * \\
(0.007)\end{array}$ & $\begin{array}{c}0.058 * * * \\
(0.006)\end{array}$ \\
\hline Ventilation type FTX & $\begin{array}{c}0.023 * * * \\
(0.006)\end{array}$ & $\begin{array}{c}0.016 * * * \\
(0.006)\end{array}$ & $\begin{array}{c}0.015 * * * \\
(0.005)\end{array}$ \\
\hline Ventilation type $\mathrm{F}$ & $\begin{array}{c}0.027^{* * *} \\
(0.004)\end{array}$ & $\begin{array}{c}0.018^{* * *} \\
(0.003)\end{array}$ & $\begin{array}{c}0.015^{* * *} \\
(0.003)\end{array}$ \\
\hline Ventilation type FT & $\begin{array}{c}0.026 * * * \\
(0.006)\end{array}$ & $\begin{array}{c}0.015^{* *} \\
(0.007)\end{array}$ & $\begin{array}{c}0.018^{* * *} \\
(0.006)\end{array}$ \\
\hline Ventilation type with recycling & $\begin{array}{c}0.040 * * * \\
(0.009)\end{array}$ & $\begin{array}{c}0.030 * * * \\
(0.008)\end{array}$ & $\begin{array}{c}0.022^{* *} \\
(0.009)\end{array}$ \\
\hline New façade 2003 or later & & $\begin{array}{c}-0.022 * * \\
(0.011)\end{array}$ & $\begin{array}{c}-0.024^{* *} \\
(0.011)\end{array}$ \\
\hline New roof 2003 or later & & $\begin{array}{c}-0.021 * * * \\
(0.006)\end{array}$ & $\begin{array}{c}-0.016^{* * *} \\
(0.005)\end{array}$ \\
\hline Simple type of windows & & $\begin{array}{c}0.018^{* * *} \\
(0.005)\end{array}$ & $\begin{array}{c}0.022^{* * *} \\
(0.005)\end{array}$ \\
\hline New kitchen equipment & & $\begin{array}{c}0.011^{* * *} \\
(0.004)\end{array}$ & $\begin{array}{c}0.013^{* * *} \\
(0.004)\end{array}$ \\
\hline 2 or more bathrooms & & $\begin{array}{c}0.011^{* * *} \\
(0.003)\end{array}$ & $\begin{array}{c}0.010 * * * \\
(0.003)\end{array}$ \\
\hline Householder age (In) & & $\begin{array}{c}-0.043^{* * *} \\
(0.004)\end{array}$ & $\begin{array}{c}-0.040 * * * \\
(0.004)\end{array}$ \\
\hline Household size (no. of residents) & & $\begin{array}{c}0.028 * * * \\
(0.001)\end{array}$ & $\begin{array}{c}0.027^{* * *} \\
(0.001)\end{array}$ \\
\hline $\begin{array}{l}\text { Disposable income of household } \\
\text { head (In) }\end{array}$ & & $0.011 * * *$ & $0.008^{* * *}$ \\
\hline
\end{tabular}




\begin{tabular}{|c|c|c|c|}
\hline \multirow{2}{*}{\multicolumn{2}{|c|}{ Higher education of household head }} & $(0.002)$ & $(0.002)$ \\
\hline & & $\begin{array}{l}-0.001 \\
(0.003)\end{array}$ & $\begin{array}{l}-0.004 \\
(0.004)\end{array}$ \\
\hline \multirow{2}{*}{$\begin{array}{l}\text { Foreign background of household } \\
\text { head }\end{array}$} & & 0.003 & 0.001 \\
\hline & & $(0.003)$ & $(0.003)$ \\
\hline At least one green car & & $\begin{array}{c}-0.017 * * * \\
(0.004)\end{array}$ & $\begin{array}{c}-0.016^{* * *} \\
(0.004)\end{array}$ \\
\hline Mean no of frost days & $\begin{array}{l}0.094^{* * *} \\
(0.019)\end{array}$ & $\begin{array}{l}-0.004 \\
(0.010)\end{array}$ & $\begin{array}{c}0.073 * * * \\
(0.015)\end{array}$ \\
\hline Constant & $\begin{array}{c}6.532 * * * \\
(0.093)\end{array}$ & $\begin{array}{c}6.560 * * * \\
(0.090)\end{array}$ & $\begin{array}{c}6.580 * * * \\
(0.066)\end{array}$ \\
\hline No of observations & 75,726 & 68,948 & 68,948 \\
\hline R-squared & 0.521 & 0.535 & 0.550 \\
\hline \multicolumn{4}{|c|}{$\begin{array}{l}\text { Table A3. Estimated impact of housing characteristics on the assessed energy conservation } \\
\text { potential. The dependent variable is the logarithm }(\mathrm{In}) \text { of the energy conservation. }\end{array}$} \\
\hline \multirow[t]{2}{*}{ VARIABLES } & $\begin{array}{l}\text { EPC variables } \\
\text { only }\end{array}$ & $\begin{array}{c}\text { EPC and other control } \\
\text { variables }\end{array}$ & $\begin{array}{l}\text { Individual firm } \\
\text { effects }\end{array}$ \\
\hline & $(1)$ & $(2)$ & $(3)$ \\
\hline Energy consumption (In) & $\begin{array}{c}2.416^{* * *} \\
(0.284)\end{array}$ & $\begin{array}{c}2.419 * * * \\
(0.284)\end{array}$ & $\begin{array}{c}2.500 * * * \\
(0.303)\end{array}$ \\
\hline Construction year 1900 or earlier & $\begin{array}{c}1.776^{* * *} \\
(0.310)\end{array}$ & $\begin{array}{c}1.735 * * * \\
(0.308)\end{array}$ & $\begin{array}{c}1.830 * * * \\
(0.339)\end{array}$ \\
\hline Construction year 1901-1920 & $\begin{array}{c}1.748 * * * \\
(0.284)\end{array}$ & $\begin{array}{c}1.707 * * * \\
(0.282)\end{array}$ & $\begin{array}{c}1.867 * * * \\
(0.296)\end{array}$ \\
\hline Construction year 1921-1940 & $\begin{array}{c}1.802 * * * \\
(0.296)\end{array}$ & $\begin{array}{c}1.750 * * * \\
(0.292)\end{array}$ & $\begin{array}{c}1.921 * * * \\
(0.300)\end{array}$ \\
\hline Construction year 1941-1960 & $\begin{array}{c}2.001 * * * \\
(0.263)\end{array}$ & $\begin{array}{c}1.946 * * * \\
(0.259)\end{array}$ & $\begin{array}{c}2.072 * * * \\
(0.280)\end{array}$ \\
\hline Construction year 1961-1970 & $\begin{array}{c}1.981^{* * *} \\
(0.256)\end{array}$ & $\begin{array}{c}1.923 * * * \\
(0.255)\end{array}$ & $\begin{array}{c}2.062 * * * \\
(0.278)\end{array}$ \\
\hline Construction year 1971-1980 & $\begin{array}{c}1.878 * * * \\
(0.287)\end{array}$ & $\begin{array}{c}1.852 * * * \\
(0.286)\end{array}$ & $\begin{array}{c}1.966 * * * \\
(0.310)\end{array}$ \\
\hline Construction year 1981-1990 & $\begin{array}{c}1.560 * * * \\
(0.254)\end{array}$ & $\begin{array}{c}1.551 * * * \\
(0.251)\end{array}$ & $\begin{array}{c}1.620 * * * \\
(0.267)\end{array}$ \\
\hline Construction year 1991-2000 & $\begin{array}{c}0.816 * * * \\
(0.203)\end{array}$ & $\begin{array}{c}0.805^{* * *} \\
(0.195)\end{array}$ & $\begin{array}{c}0.868 * * * \\
(0.190)\end{array}$ \\
\hline Semi-detached house & $\begin{array}{c}-0.237^{* * *} \\
(0.050)\end{array}$ & $\begin{array}{c}-0.212^{* * *} \\
(0.050)\end{array}$ & $\begin{array}{c}-0.176^{* * *} \\
(0.035)\end{array}$ \\
\hline Duplex house & $\begin{array}{c}-0.499 * * * \\
(0.077)\end{array}$ & $\begin{array}{c}-0.483^{* * *} \\
(0.077)\end{array}$ & $\begin{array}{c}-0.438^{* * *} \\
(0.063)\end{array}$ \\
\hline Heated floor area sqm (In) & $\begin{array}{c}-1.050^{* * *} \\
(0.252)\end{array}$ & $\begin{array}{c}-1.016^{* * *} \\
(0.254)\end{array}$ & $\begin{array}{c}-1.054^{* * *} \\
(0.263)\end{array}$ \\
\hline Electricity \& (any type of) heat pump & $\begin{array}{l}-2.812^{* * *} \\
(0.390)\end{array}$ & $\begin{array}{l}-2.804^{* * *} \\
(0.389)\end{array}$ & $\begin{array}{l}-2.816^{* * *} \\
(0.398)\end{array}$ \\
\hline Only district heating & $\begin{array}{c}-1.731^{* * *} \\
(0.164)\end{array}$ & $\begin{array}{c}-1.728^{* * *} \\
(0.164)\end{array}$ & $\begin{array}{c}-1.821 * * * \\
(0.165)\end{array}$ \\
\hline
\end{tabular}




\begin{tabular}{|c|c|c|c|}
\hline Electricity \& wood & $\begin{array}{c}-1.131^{* * *} \\
(0.173)\end{array}$ & $\begin{array}{c}-1.130 * * * \\
(0.174)\end{array}$ & $\begin{array}{c}-1.161^{* * *} \\
(0.171)\end{array}$ \\
\hline Only biofuels & $\begin{array}{c}-2.050 * * * \\
(0.181)\end{array}$ & $\begin{array}{c}-2.050 * * * \\
(0.182)\end{array}$ & $\begin{array}{c}-2.125 * * * \\
(0.180)\end{array}$ \\
\hline $\begin{array}{l}\text { Electricity, biofuels and (any type of) } \\
\text { heat pump }\end{array}$ & $\begin{array}{c}-2.813^{* * *} \\
(0.246)\end{array}$ & $\begin{array}{c}-2.800 * * * \\
(0.246)\end{array}$ & $\begin{array}{c}-2.857 * * * \\
(0.232)\end{array}$ \\
\hline Electricity \& oil-fired boiler & $\begin{array}{l}0.099 \\
(0.187)\end{array}$ & $\begin{array}{l}0.083 \\
(0.185)\end{array}$ & $\begin{array}{l}0.053 \\
(0.175)\end{array}$ \\
\hline Only water/air/waste air heat pump & $\begin{array}{c}-2.910 * * * \\
(0.361)\end{array}$ & $\begin{array}{c}-2.911^{* * *} \\
(0.361)\end{array}$ & $\begin{array}{c}-2.908 * * * \\
(0.360)\end{array}$ \\
\hline Only ground sourced heat pump & $\begin{array}{c}-3.266 * * * \\
(0.451)\end{array}$ & $\begin{array}{c}-3.249 * * * \\
(0.450)\end{array}$ & $\begin{array}{c}-3.230^{* * *} \\
(0.458)\end{array}$ \\
\hline $\begin{array}{l}\text { Combination of electricity and } \\
\text { biofuels }\end{array}$ & $\begin{array}{c}-2.003 * * * \\
(0.296)\end{array}$ & $\begin{array}{c}-2.011 * * * \\
(0.297)\end{array}$ & $\begin{array}{c}-2.062^{* * *} \\
(0.292)\end{array}$ \\
\hline Other types of energy sources & $\begin{array}{c}-1.813^{* * *} \\
(0.197)\end{array}$ & $\begin{array}{c}-1.809 * * * \\
(0.197)\end{array}$ & $\begin{array}{c}-1.847^{* * *} \\
(0.184)\end{array}$ \\
\hline Ventilation type FTX & $\begin{array}{c}-0.563 * * * \\
(0.103)\end{array}$ & $\begin{array}{c}-0.537^{* * *} \\
(0.104)\end{array}$ & $\begin{array}{c}-0.430 * * * \\
(0.109)\end{array}$ \\
\hline Ventilation type $\mathrm{F}$ & $\begin{array}{c}-0.384 * * * \\
(0.075)\end{array}$ & $\begin{array}{c}-0.360 * * * \\
(0.075)\end{array}$ & $\begin{array}{c}-0.281^{* * *} \\
(0.081)\end{array}$ \\
\hline Ventilation type FT & $\begin{array}{c}-0.363^{* * *} \\
(0.092)\end{array}$ & $\begin{array}{c}-0.339 * * * \\
(0.093)\end{array}$ & $\begin{array}{c}-0.376 * * * \\
(0.081)\end{array}$ \\
\hline Ventilation type with recycling & $\begin{array}{c}-0.554^{* *} \\
(0.246)\end{array}$ & $\begin{array}{l}-0.530 * * \\
(0.246)\end{array}$ & $\begin{array}{l}-0.219 \\
(0.236)\end{array}$ \\
\hline New façade 2003 or later & & $\begin{array}{c}-0.348^{* * *} \\
(0.097)\end{array}$ & $\begin{array}{c}-0.328 * * * \\
(0.098)\end{array}$ \\
\hline New roof 2003 or later & & $\begin{array}{c}-0.155^{* *} \\
(0.076)\end{array}$ & $\begin{array}{c}-0.188 * * \\
(0.078)\end{array}$ \\
\hline Simple type of windows & & $\begin{array}{c}0.202 * * * \\
(0.077)\end{array}$ & $\begin{array}{c}0.160^{* *} \\
(0.069)\end{array}$ \\
\hline New kitchen equipment & & $\begin{array}{c}-0.204^{* * *} \\
(0.069)\end{array}$ & $\begin{array}{c}-0.194^{* * *} \\
(0.067)\end{array}$ \\
\hline 2 or more bathrooms & & $\begin{array}{c}-0.143^{* * *} \\
(0.024)\end{array}$ & $\begin{array}{c}-0.152^{* * *} \\
(0.023)\end{array}$ \\
\hline Mean no of frost days & & $\begin{array}{c}0.179 \\
(0.195)\end{array}$ & $\begin{array}{c}0.069 \\
(0.268)\end{array}$ \\
\hline Constant & $\begin{array}{c}-16.483^{* * *} \\
(2.112)\end{array}$ & $\begin{array}{c}-16.524^{* * *} \\
(2.104)\end{array}$ & $\begin{array}{c}-12.589 * * * \\
(2.170)\end{array}$ \\
\hline No of observations & 75,726 & 75,261 & 75,261 \\
\hline R-squared & 0.466 & 0.467 & 0.493 \\
\hline
\end{tabular}


Table A4. The estimated impact of housing and location attributes on the transaction price. The dependent variable is the logarithm (In) of the transaction price.

\begin{tabular}{|c|c|c|c|c|}
\hline VARIABLES & $(1)$ & $(2)$ & (3) & $(4)$ \\
\hline Construction year 1900 or earlier & $\begin{array}{c}-0.269 * * * \\
(0.013)\end{array}$ & $\begin{array}{c}-0.267 * * * \\
(0.013)\end{array}$ & $\begin{array}{c}-0.265 * * * \\
(0.013)\end{array}$ & $\begin{array}{c}-0.264 * * * \\
(0.013)\end{array}$ \\
\hline Construction year $1901-1920$ & $\begin{array}{c}-0.392 * * * \\
(0.010)\end{array}$ & $\begin{array}{c}-0.394 * * * * \\
(0.010)\end{array}$ & $\begin{array}{c}-0.387 * * * * \\
(0.009)\end{array}$ & $\begin{array}{c}-0.389 * * * \\
(0.010)\end{array}$ \\
\hline Construction year $1921-1940$ & $\begin{array}{c}-0.441 * * * \\
(0.008)\end{array}$ & $\begin{array}{c}-0.442 * * * \\
(0.008)\end{array}$ & $\begin{array}{c}-0.436 * * * \\
(0.008)\end{array}$ & $\begin{array}{c}-0.438 * * * \\
(0.008)\end{array}$ \\
\hline Construction year $1941-1960$ & $\begin{array}{c}-0.495 * * * \\
(0.008)\end{array}$ & $\begin{array}{c}-0.495^{* * *} * \\
(0.008)\end{array}$ & $\begin{array}{c}-0.487 * * * \\
(0.008)\end{array}$ & $\begin{array}{c}-0.488^{* * *} \\
(0.008)\end{array}$ \\
\hline Construction year $1961-1970$ & $\begin{array}{c}-0.402 * * * \\
(0.007)\end{array}$ & $\begin{array}{c}-0.401 * * * \\
(0.007)\end{array}$ & $\begin{array}{c}-0.396^{* * * *} \\
(0.007)\end{array}$ & $\begin{array}{c}-0.396 * * * \\
(0.007)\end{array}$ \\
\hline Construction year $1971-1980$ & $\begin{array}{c}-0.371 * * * \\
(0.006)\end{array}$ & $\begin{array}{c}-0.370 * * * \\
(0.007)\end{array}$ & $\begin{array}{c}-0.368 * * * \\
(0.006)\end{array}$ & $\begin{array}{c}-0.368 * * * \\
(0.007)\end{array}$ \\
\hline Construction year $1981-1990$ & $\begin{array}{c}-0.244 * * * \\
(0.006)\end{array}$ & $\begin{array}{c}-0.244 * * * \\
(0.007)\end{array}$ & $\begin{array}{c}-0.242 * * * \\
(0.006)\end{array}$ & $\begin{array}{c}-0.243^{* * *} \\
(0.006)\end{array}$ \\
\hline Construction year $1991-2000$ & $\begin{array}{c}-0.136 * * * \\
(0.007)\end{array}$ & $\begin{array}{c}-0.137 * * * \\
(0.007)\end{array}$ & $\begin{array}{c}-0.135^{* * *} \\
(0.007)\end{array}$ & $\begin{array}{c}-0.136^{* * *} \\
(0.007)\end{array}$ \\
\hline Heated floor area sqm (In) & $\begin{array}{c}0.435^{* * *} * \\
(0.006)\end{array}$ & $\begin{array}{c}0.435^{* * * *} \\
(0.006)\end{array}$ & $\begin{array}{c}0.439 * * * \\
(0.006)\end{array}$ & $\begin{array}{c}0.435 * * * \\
(0.006)\end{array}$ \\
\hline Electricity \& (any type of) heat pump & $\begin{array}{c}0.071^{* * *} \\
(0.004)\end{array}$ & $\begin{array}{c}0.071 \text { *** } \\
(0.005)\end{array}$ & $\begin{array}{c}0.050 * * * \\
(0.004)\end{array}$ & $\begin{array}{c}0.051^{* * * *} \\
(0.005)\end{array}$ \\
\hline Only district heating & $\begin{array}{c}0.083 * * * \\
(0.005)\end{array}$ & $\begin{array}{c}0.083 * * * \\
(0.005)\end{array}$ & $\begin{array}{c}0.070^{* * *} * \\
(0.005)\end{array}$ & $\begin{array}{c}0.068 \text { *** } \\
(0.005)\end{array}$ \\
\hline Electricity \& wood & $\begin{array}{l}-0.008 \\
(0.007)\end{array}$ & $\begin{array}{l}-0.007 \\
(0.007)\end{array}$ & $\begin{array}{c}-0.019 * * * \\
(0.007)\end{array}$ & $\begin{array}{c}-0.019 * * * \\
(0.007)\end{array}$ \\
\hline Only biofuels & $\begin{array}{c}-0.139 * * * \\
(0.009)\end{array}$ & $\begin{array}{c}-0.136^{* * * *} \\
(0.009)\end{array}$ & $\begin{array}{c}-0.156^{* * * *} \\
(0.009)\end{array}$ & $\begin{array}{c}-0.158^{* * * *} \\
(0.009)\end{array}$ \\
\hline Electricity, biofuels and (any type of) heat pump & $\begin{array}{c}0.053^{* * *} * \\
(0.007)\end{array}$ & $\begin{array}{c}0.050^{* * *} \\
(0.007)\end{array}$ & $\begin{array}{c}0.031 * * * \\
(0.007)\end{array}$ & $\begin{array}{c}0.026 * * * \\
(0.007)\end{array}$ \\
\hline Electricity \& oil-fired boiler & $\begin{array}{c}-0.106^{* * * *} \\
(0.015)\end{array}$ & $\begin{array}{c}-0.107 * * * \\
(0.015)\end{array}$ & $\begin{array}{c}-0.097 * * * \\
(0.016)\end{array}$ & $\begin{array}{c}-0.098 * * * \\
(0.016)\end{array}$ \\
\hline Only water/air/waste air heat pump & $\begin{array}{c}0.080 * * * \\
(0.006)\end{array}$ & $\begin{array}{c}0.082^{* * * *} \\
(0.006)\end{array}$ & $\begin{array}{c}0.059 * * * \\
(0.006)\end{array}$ & $\begin{array}{c}0.061 * * * * \\
(0.006)\end{array}$ \\
\hline Only ground sourced heat pump & $\begin{array}{c}0.165^{* * *} \\
(0.006)\end{array}$ & $\begin{array}{c}0.166^{* * *} * \\
(0.006)\end{array}$ & $\begin{array}{c}0.139 * * * \\
(0.006)\end{array}$ & $\begin{array}{c}0.141 * * * \\
(0.006)\end{array}$ \\
\hline Combination of electricity and biofuels & $\begin{array}{c}-0.070 \text { *** } \\
(0.012)\end{array}$ & $\begin{array}{c}-0.069 * * * \\
(0.012)\end{array}$ & $\begin{array}{c}-0.086^{* * *} \\
(0.012)\end{array}$ & $\begin{array}{c}-0.088^{* * *} * \\
(0.012)\end{array}$ \\
\hline Other types of energy sources & $\begin{array}{c}0.041^{* * *} \\
(0.005)\end{array}$ & $\begin{array}{c}0.042 * * * \\
(0.005)\end{array}$ & $\begin{array}{c}0.031 * * * \\
(0.005)\end{array}$ & $\begin{array}{c}0.031^{* * * *} \\
(0.005)\end{array}$ \\
\hline Ventilation type with recycling & $\begin{array}{c}0.017 * * * \\
(0.006)\end{array}$ & $\begin{array}{c}0.019 * * * \\
(0.006)\end{array}$ & $\begin{array}{c}0.016^{* * *} \\
(0.006)\end{array}$ & $\begin{array}{c}0.019 * * * \\
(0.006)\end{array}$ \\
\hline Ventilation type FT & $\begin{array}{c}0.036 \text { *** } \\
(0.008)\end{array}$ & $\begin{array}{c}0.038^{* * *} * \\
(0.008)\end{array}$ & $\begin{array}{c}0.035 * * * \\
(0.008)\end{array}$ & $\begin{array}{c}0.037 * * * * \\
(0.008)\end{array}$ \\
\hline Ventilation type $F$ & $\begin{array}{c}0.046 * * * \\
(0.004)\end{array}$ & $\begin{array}{c}0.047 * * * \\
(0.004)\end{array}$ & $\begin{array}{c}0.045^{* * * *} \\
(0.004)\end{array}$ & $\begin{array}{c}0.046^{* * * *} \\
(0.004)\end{array}$ \\
\hline Ventilation type FTX & $\begin{array}{c}0.055^{* * *} * \\
(0.005)\end{array}$ & $\begin{array}{c}0.057 * * * \\
(0.005)\end{array}$ & $\begin{array}{c}0.054 * * * \\
(0.005)\end{array}$ & $\begin{array}{c}0.055^{* * * *} \\
(0.005)\end{array}$ \\
\hline New façade 2003 or later & $0.046^{* * *}$ & $0.042 * * *$ & $0.046^{* * *}$ & $0.040 * * *$ \\
\hline
\end{tabular}




\begin{tabular}{|c|c|c|c|c|}
\hline & $(0.014)$ & $(0.014)$ & $(0.014)$ & $(0.014)$ \\
\hline New roof 2003 or later & $\begin{array}{c}0.026 * * * \\
(0.008)\end{array}$ & $\begin{array}{c}0.029 * * * \\
(0.008)\end{array}$ & $\begin{array}{c}0.024 * * * \\
(0.008)\end{array}$ & $\begin{array}{c}0.028 * * * \\
(0.008)\end{array}$ \\
\hline Window type simple & $\begin{array}{c}-0.018^{*} \\
(0.010)\end{array}$ & $\begin{array}{c}-0.020 * * \\
(0.010)\end{array}$ & $\begin{array}{r}-0.018^{*} \\
(0.010)\end{array}$ & $\begin{array}{c}-0.020 * * \\
(0.010)\end{array}$ \\
\hline New kitchen equipment & $\begin{array}{c}0.073 * * * \\
(0.006)\end{array}$ & $\begin{array}{c}0.073 * * * \\
(0.006)\end{array}$ & $\begin{array}{c}0.072 * * * \\
(0.006)\end{array}$ & $\begin{array}{c}0.073 * * * \\
(0.006)\end{array}$ \\
\hline 2 or more bathrooms & $\begin{array}{c}0.036^{* * * *} \\
(0.003)\end{array}$ & $\begin{array}{c}0.036 \text { *** } \\
(0.003)\end{array}$ & $\begin{array}{c}0.035^{* * * *} \\
(0.003)\end{array}$ & $\begin{array}{c}0.035 * * * \\
(0.003)\end{array}$ \\
\hline Property plot, sqm (In) & $\begin{array}{c}0.062 * * * \\
(0.002)\end{array}$ & $\begin{array}{c}0.061 * * * \\
(0.002)\end{array}$ & $\begin{array}{c}0.063 * * * \\
(0.002)\end{array}$ & $\begin{array}{c}0.062 * * * \\
(0.002)\end{array}$ \\
\hline Open fireplace & $\begin{array}{c}0.097 * * * \\
(0.003)\end{array}$ & $\begin{array}{c}0.097 * * * \\
(0.003)\end{array}$ & $\begin{array}{c}0.098 * * * \\
(0.003)\end{array}$ & $\begin{array}{c}0.098 * * * \\
(0.003)\end{array}$ \\
\hline Living or recreation room in basement & $\begin{array}{c}-0.056^{* * * *} \\
(0.005)\end{array}$ & $\begin{array}{c}-0.056^{* * * *} \\
(0.005)\end{array}$ & $\begin{array}{c}-0.056^{* * *} * \\
(0.005)\end{array}$ & $\begin{array}{c}-0.056^{* * * *} \\
(0.005)\end{array}$ \\
\hline Kitchen standard: simple & $\begin{array}{c}-0.108^{* * *} \\
(0.004)\end{array}$ & $\begin{array}{c}-0.108 * * * \\
(0.004)\end{array}$ & $\begin{array}{c}-0.105^{* * *} \\
(0.004)\end{array}$ & $\begin{array}{c}-0.105^{* * * *} \\
(0.004)\end{array}$ \\
\hline Kitchen standard: high & $\begin{array}{c}0.072 * * * \\
(0.005)\end{array}$ & $\begin{array}{c}0.074 * * * \\
(0.005)\end{array}$ & $\begin{array}{c}0.071 * * * \\
(0.005)\end{array}$ & $\begin{array}{c}0.073 * * * \\
(0.005)\end{array}$ \\
\hline Recently rebuilt or extended & $\begin{array}{c}0.136^{* * * *} \\
(0.007)\end{array}$ & $\begin{array}{c}0.136 * * * \\
(0.007)\end{array}$ & $\begin{array}{c}0.133 * * * \\
(0.007)\end{array}$ & $\begin{array}{c}0.133 * * * \\
(0.007)\end{array}$ \\
\hline Private shoreline or beach & $\begin{array}{c}0.645^{* * *} * \\
(0.026)\end{array}$ & $\begin{array}{c}0.646 \text { *** } \\
(0.026)\end{array}$ & $\begin{array}{c}0.650 * * * \\
(0.026)\end{array}$ & $\begin{array}{c}0.650 * * * \\
(0.026)\end{array}$ \\
\hline $0-75 \mathrm{~m}$ to shoreline or beach & $\begin{array}{c}0.276^{* * *} * \\
(0.015)\end{array}$ & $\begin{array}{c}0.271 * * * \\
(0.015)\end{array}$ & $\begin{array}{c}0.275 * * * \\
(0.015)\end{array}$ & $\begin{array}{c}0.271 * * * \\
(0.015)\end{array}$ \\
\hline $76-150 \mathrm{~m}$ to shoreline or beach & $\begin{array}{c}0.138 * * * \\
(0.010)\end{array}$ & $\begin{array}{c}0.137 * * * \\
(0.010)\end{array}$ & $\begin{array}{c}0.139 * * * \\
(0.010)\end{array}$ & $\begin{array}{c}0.137 * * * \\
(0.010)\end{array}$ \\
\hline Mean number of frost days & $\begin{array}{c}-0.293 * * * \\
(0.012)\end{array}$ & $\begin{array}{c}-0.295^{* * *} \\
(0.012)\end{array}$ & $\begin{array}{c}-0.292 * * * \\
(0.012)\end{array}$ & $\begin{array}{c}-0.293 * * * \\
(0.012)\end{array}$ \\
\hline Share of green votes in the municip. & $\begin{array}{c}0.192 * * * \\
(0.005)\end{array}$ & $\begin{array}{c}0.198^{* * *} * \\
(0.005)\end{array}$ & $\begin{array}{c}0.192 * * * \\
(0.005)\end{array}$ & $\begin{array}{c}0.197 * * * \\
(0.005)\end{array}$ \\
\hline Municipality tax & $\begin{array}{c}-0.701 * * * \\
(0.040)\end{array}$ & $\begin{array}{c}-0.702 * * * \\
(0.041)\end{array}$ & $\begin{array}{c}-0.716^{* * *} \\
(0.040)\end{array}$ & $\begin{array}{c}-0.717 * * * \\
(0.041)\end{array}$ \\
\hline Mean parish income, KEUR (In) & $\begin{array}{c}1.374 * * * \\
(0.018)\end{array}$ & $\begin{array}{c}1.367 * * * \\
(0.018)\end{array}$ & $\begin{array}{c}1.371 * * * \\
(0.018)\end{array}$ & $\begin{array}{c}1.362 * * * \\
(0.018)\end{array}$ \\
\hline Parish population density per sqkm (In) & $\begin{array}{c}0.178 * * * \\
(0.001)\end{array}$ & $\begin{array}{c}0.178 * * * \\
(0.001)\end{array}$ & $\begin{array}{c}0.178 * * * \\
(0.001)\end{array}$ & $\begin{array}{c}0.177 * * * \\
(0.001)\end{array}$ \\
\hline Constant & $\begin{array}{c}-9.397 * * * \\
(0.265)\end{array}$ & $\begin{array}{c}-9.306 * * * \\
(0.270)\end{array}$ & $\begin{array}{c}-9.331 * * * \\
(0.265)\end{array}$ & $\begin{array}{c}-9.289 * * * \\
(0.269)\end{array}$ \\
\hline No of observations & 69,698 & 67,961 & 68,926 & 67,244 \\
\hline R-squared & 0.761 & 0.759 & 0.762 & 0.760 \\
\hline
\end{tabular}

Robust standard errors in parentheses $* * * p<0.01,{ }^{* *} p<0.05,{ }^{*} p<0.1$

Time and regional effects are included. 